\title{
Analysis of the Extent to which Critical Thinking is Promoted in Examination Questions in the History High School Matriculation Examination Papers of Australia and Croatia
}

\section{Tania Blažević}

\author{
Senior lecturer, Faculty of Law, Unversity of Split
} tblazevic@pravst.hr

\author{
Doi:10.5901/jesr.2013.v4n3p351
}

\begin{abstract}
High school leaving matriculation examination papers are taken by final year high school students and contribute to university entrance in both the countries of Australia and Croatia. A hierarchical critical thinking taxonomy was developed based on similar taxonomies in existing literature in order to research the questions in the History high school matriculation examination papers of Australia and Croatia respectively in terms of critical thinking. The examination questions were where necessary translated into English and then classified according to this taxonomy and the results are displayed according to the level of critical thinking demanded in these examination papers. The similarities and differences in the findings between the examination paper questions of the two countries in terms of critical thinking were compared and closely studied. Based on these results, conclusions and implications for further consequences of matriculation examination results, for example, university entrance, teaching, learning and good citizenship were then examined.
\end{abstract}

Keywords: critical thinking, examination questions, taxonomy

\section{Introduction}

The purpose of this paper is to categorize the examination questions of two comparative school leaving subjects; the 2009 Australian Victorian Certificate of Education examination paper in history and the 2010 Croatian Matura Matriculation examination paper in history according to a model of critical thinking. This model of thinking was influenced by the various critical thinking taxonomies which contain obvious overlapping in the levels of thinking which constitute critical thinking. (Paul, 1996) ${ }^{1}$

\section{Rationale}

The elements by which I propose to categorise the school leaving examination questions would best be summarised by Anderson and Krathwohl's ${ }^{2}$ revision of Bloom's taxonomy $(1956)^{3}$ of critical thinking.

My suggested model is the following hierarchy with item 6 classified as being at the highest level of critical thinking down to item one which is the lowest level of critical thinking.

1. Creating producing new arguments, ideas and heuristic solutions inspired by output of given information.

2. Assessing Assessing given information, providing valued judgements about information, with justifiable reasons.

3. Analysing Interpreting information determining the causes and consequences of information

4. Applying Comparing and contrasting both previous and given information

5. Understanding Demonstrating understanding of pre-learned and given information by explaining

6. Remembering Providing pre-learned information and facts.

\footnotetext{
${ }_{1}^{1}$ Paul

${ }^{2}$ Anderson, Lorin W and Krathwohl, David R 2001 A Taxonomy for learning, Teaching and Assessing: a Revsion of Bloom's Taxonomy.New York. Longman

${ }^{3}$ Bloom, B. S. (ed.) (1956) Taxonomy of Educational Objectives, the classification of educational goals - Handbook I: Cognitive Domain New York: McKay 37Huitt, W. (2009). Bloom et al.'s taxonomy of the cognitive domain. Educational Psychology Interactive. Valdosta, GA: Valdosta State University. Retrieved [date], from http://www.edpsycinteractive.org/topics/cogsys/bloom.html 38Langrehr J (2005) Assessing Creative and Critical Thinking Hawker Brwnlow
} 
This model seems to best summarise what critical thinking skills are in an hierarchical form and seem to be the most logical for the kind of document analysis of examination questions that I am proposing. It can be applied easily in particular to questions, as it is questions in particular that I will be categorising in terms of the critical skill demanded. As Bloom purports, creative thinking together with high levels of critical thinking require highest levels of brain activity. ${ }^{4}$

Precisely, I pinpointed what each question in the examination is demanding in terms of my taxonomy's skills. I categorised the skills asked by the questions in term of my taxonomy and then I will display in graphical form the frequency of each asked skill. If more than one skill is demanded from the question, I noted both and specify whether the question demanded one or more skills and what those skills are. Therefore, the number of questions was specified as well as what skill/s is/are being asked in each question.

\section{Description of Examinations}

\subsection{Croatia Matura History examination paper 2010. School year is from September to June.}

The examination paper is comprised of:

Part 1: 1-20. 20 Multiple Choice questions with A, B, C and D options which consist of a single word. One question has a map as input and one question has an illustration as input.

Part 2: 21-30. 10 Sentences of Fill in the Gap with the Missing Word Task.

Part 3: 31-37. 6 Multiple Choice questions with the options comprised of historical events sequences.

Part 4: 38.1-50.4. 13 Matching Tasks, each one containing 4 matches. Matching given historical events, eras, historical items or people with other phrases, or matching phrases with marked areas on a map or illustrations.

Part 5: 50.1- 60.3. 31 questions. Answer each question with a word or term based on an input map or illustration.

Each correct answer is worth one point. Total number of points: 119

Duration of examination: 90 minutes

\subsection{Australian VHC History examination paper 2009. The school year is from January to December}

The examination comprises four sections as follows;

Section A: In response to an illustration or excerpt from a text and drawing on knowledge gained from studying history in school, students answer 3 questions in written, complete sentences, paragraph form. 20 marks made up of question 1ai worth 2, 1a ii worth 4 marks, 1aiii worth 6 marks, and 1aiv worth 8 marks.

Section B: Drawing on knowledge from a chapter in the high school history textbook, students answer 3 questions in written, complete sentences, paragraph form. 20 marks made up of 2a worth 4 marks, $2 \mathrm{~b}$ worth 6 marks and $2 \mathrm{c}$ worth 10 marks.

Section C: Write an essay choosing from 3 given topics worth 20 marks.

Section D: Choosing one of and based on one of 4 given documents/ illustrations, and simultaneously based on a chapter of the high school history textbook, students respond to a question in written, complete sentences, paragraph form worth 20 marks.

Total number of marks: 80

Duration of examination: 120 minutes with 15 minutes reading time.

\subsection{Categorisation of questions}

Categorisation of the examination questions will be based on the above suggested critical thinking scale with item 6 classified as being at the highest level of critical thinking and one is the lowest..

Croatia History Examination

N.B. Questions 1-20, and 31-37 have given options A-D from which students choose their answer.

Questions 3,9, 14, 20,41, 43, 44,48, 49,51.1-51.352.1-52.3,54.1-54.3, 55.1-55.3, 56.1-56.3,57.1-57.3,58.1-58.3,59.1-59.3,

60.1-60.3 have input based on a map, picture or text excerpt

${ }_{4}^{4}$ Bloom, B. S. (ed.) (1956) Taxonomy of Educational Objectives, the classification of educational goals - Handbook I: Cognitive Domain New York: McKay 


\begin{tabular}{|c|c|}
\hline Question & Rating On Critical Thinking Scale \\
\hline $\begin{array}{l}\text { 1. Of the following, what is the most significanz invention of the } \\
\text { Mesolithic age? }\end{array}$ & \\
\hline $\begin{array}{l}\text { 2. Which class of Romans contributed the most to the } \\
\text { Romanisation of Illyrian areas? }\end{array}$ & $\begin{array}{l}\text { 1. Remembering and providing pre-learned facts } \\
\text { and information }\end{array}$ \\
\hline $\begin{array}{l}\text { 3. What is the name of the group of nations whose emigration is } \\
\text { displayed on the map? }\end{array}$ & $\begin{array}{l}\text { 1. Remembering and providing pre-learned facts } \\
\text { and information }\end{array}$ \\
\hline $\begin{array}{l}\text { 4. Which Roman Emperor established the first Roman province } \\
\text { within contemporary Croatian territory? }\end{array}$ & $\begin{array}{l}\text { 1. Remembering and providing pre-learned facts } \\
\text { and information }\end{array}$ \\
\hline 5. What is the name of the port of the city of Athens? & $\begin{array}{l}\text { 1. Remembering and providing pre-learned facts } \\
\text { and } 1 \text {. Remembering and providing pre-learned } \\
\text { facts and information }\end{array}$ \\
\hline $\begin{array}{l}\text { 6. In which principality did Cyril and Method act as opposition } \\
\text { against German influence? }\end{array}$ & $\begin{array}{l}\text { 1. Remembering and providing pre-learned facts } \\
\text { and information }\end{array}$ \\
\hline $\begin{array}{l}\text { 7. In what kind of union were Croatia and Hungary after the year } \\
\text { of } 1102 \text { ? }\end{array}$ & $\begin{array}{l}\text { 1. Remembering and providing pre-learned facts } \\
\text { and information }\end{array}$ \\
\hline $\begin{array}{l}\text { 8. Which period of central Europe's history is characterised by the } \\
\text { renewed slave-monetary economy? }\end{array}$ & $\begin{array}{l}\text { 1. Remembering and providing pre-learned facts } \\
\text { and information }\end{array}$ \\
\hline $\begin{array}{l}\text { 9. Which crusade war resulted in the division of the Byzantine } \\
\text { Empire as displayed on the map provided? }\end{array}$ & $\begin{array}{l}\text { 1. Remembering and providing pre-learned facts } \\
\text { and information }\end{array}$ \\
\hline $\begin{array}{l}\text { 10. Which battle was Croatia's biggest defeat in its war of } \\
\text { defence against the Turks? } \\
\text { 11. Which political body in the year } 1792 \text { proclaimed France as a } \\
\text { Republic? }\end{array}$ & $\begin{array}{l}\text { 1. Remembering and providing pre-learned facts } \\
\text { and information }\end{array}$ \\
\hline $\begin{array}{l}\text { 12. Under which political pressure did the Croatian governor Ivan } \\
\text { Erdödy defend Croatian municipal rights with the statement } \\
\text { Regnum regno non proscribit leges („The kingdom does not } \\
\text { prescribe the law to the kingdom”)? }\end{array}$ & $\begin{array}{l}\text { 1. Remembering and providing pre-learned facts } \\
\text { and information }\end{array}$ \\
\hline $\begin{array}{l}\text { 13. In Zagreb in 1794, who set up "a printing press to publish } \\
\text { Illyria books"? }\end{array}$ & $\begin{array}{l}\text { 1. Remembering and providing pre-learned facts } \\
\text { and information }\end{array}$ \\
\hline $\begin{array}{l}\text { 14. Which ruler tried to Europeanise his tribe by acting in the way } \\
\text { shown in the picture? }\end{array}$ & $\begin{array}{l}\text { 1. Remembering and providing pre-learned facts } \\
\text { and information }\end{array}$ \\
\hline $\begin{array}{l}\text { 15. Which of the following Croatian political issues remained } \\
\text { unresolved during the 19th century } \\
\text { until the fall of the Austro-Hungarian Empire? }\end{array}$ & $\begin{array}{l}\text { 1. Remembering and providing pre-learned facts } \\
\text { and information }\end{array}$ \\
\hline $\begin{array}{l}\text { 16. Which of the following countries was the first to come out of } \\
\text { World War I? }\end{array}$ & $\begin{array}{l}\text { 1. Remembering and providing pre-learned facts } \\
\text { and information }\end{array}$ \\
\hline $\begin{array}{l}\text { 17. With which political party did the Croatian Peasant Party start } \\
\text { a coalition in the year of } 1927 ?\end{array}$ & $\begin{array}{l}\text { 1. Remembering and providing pre-learned facts } \\
\text { and information }\end{array}$ \\
\hline $\begin{array}{l}\text { 18. By which document was the opposition with Vlado Maček as } \\
\text { its head united against the } \\
\text { Octoroon Constitution of the Kingdom of Yugoslavia? }\end{array}$ & $\begin{array}{l}\text { 1. Remembering and providing pre-learned facts } \\
\text { and information }\end{array}$ \\
\hline $\begin{array}{l}\text { 19. Today what is celebrated in the Republic of Croatia on May } \\
\text { 30th? }\end{array}$ & $\begin{array}{l}\text { 1. Remembering and providing pre-learned facts } \\
\text { and information }\end{array}$ \\
\hline $\begin{array}{l}\text { 20. What period of European history characterises the political } \\
\text { division shown on the map provided? }\end{array}$ & $\begin{array}{l}\text { 1. Remembering and providing pre-learned facts } \\
\text { and information }\end{array}$ \\
\hline $\begin{array}{l}\text { 21. The Roman Colony in the Valley of the Neretva River was } \\
\text { called }\end{array}$ & $\begin{array}{l}\text { 1. Remembering and providing pre-learned facts } \\
\text { and information }\end{array}$ \\
\hline 22. The cradle of humanity is the continent of & $\begin{array}{l}\text { 1. Remembering and providing pre-learned facts } \\
\text { and information }\end{array}$ \\
\hline $\begin{array}{l}\text { 23. The wars which led to the crisis of the survival of cities- states } \\
\text { (polisa) in Ancient Greece are }\end{array}$ & $\begin{array}{l}\text { 1. Remembering and providing pre-learned facts } \\
\text { and information }\end{array}$ \\
\hline $\begin{array}{l}\text { 24. In the period of the developed Middle Ages, support for rulers } \\
\text { in strengthening centres of power was offered by the population } \\
\text { of }\end{array}$ & $\begin{array}{l}\text { 1. Remembering and providing pre-learned facts } \\
\text { and information }\end{array}$ \\
\hline $\begin{array}{l}\text { 25. The Venetians lost territory by peaceful means from } \\
\text { Kvarnera to Drač in1358 } \\
\text { in }\end{array}$ & $\begin{array}{l}\text { 1. Remembering and providing pre-learned facts } \\
\text { and information }\end{array}$ \\
\hline
\end{tabular}




\begin{tabular}{|c|c|}
\hline $\begin{array}{l}\text { 26. The first Croatian railroad, in use from 1862, through Zagreb } \\
\text { linked the towns of Zidani Most and }\end{array}$ & $\begin{array}{l}\text { 1. Remembering and providing pre-learned facts } \\
\text { and information }\end{array}$ \\
\hline $\begin{array}{l}\text { 27. The Second Reich or Second German Empire was } \\
\text { proclaimed on18th January, } 1871 \text { in }\end{array}$ & $\begin{array}{l}\text { 1. Remembering and providing pre-learned facts } \\
\text { and information }\end{array}$ \\
\hline $\begin{array}{l}\text { 28. Antifascist Day is celebrated in Croatia on 22nd June to } \\
\text { commemorate the formation of }\end{array}$ & $\begin{array}{l}\text { 1. Remembering and providing pre-learned facts } \\
\text { and information }\end{array}$ \\
\hline $\begin{array}{l}\text { 29. The most well known person who was a victim of an } \\
\text { orchestrated political trial in post-communist Yugoslavia was } \\
\text { Zagreb Archbishop }\end{array}$ & $\begin{array}{l}\text { 1. Remembering and providing pre-learned facts } \\
\text { and information }\end{array}$ \\
\hline $\begin{array}{l}\text { 30. The beginning of the fall of Communism in Europe started in } \\
\text { November } 1989 \text { with the fall of the }\end{array}$ & $\begin{array}{l}\text { 1. Remembering and providing pre-learned facts } \\
\text { and information }\end{array}$ \\
\hline $\begin{array}{l}\text { 31. Which of the following sequences determines the correct } \\
\text { chronological order of the use of these materials? }\end{array}$ & $\begin{array}{l}\text { 1. Remembering and providing pre-learned facts } \\
\text { and information }\end{array}$ \\
\hline $\begin{array}{l}\text { 32. Which of the following sequences correctly determines the } \\
\text { chronological order of the work of Athenian reformers? }\end{array}$ & $\begin{array}{l}\text { 1. Remembering and providing pre-learned facts } \\
\text { and information }\end{array}$ \\
\hline $\begin{array}{l}\text { 33. Which of the following sequences correctly determines the } \\
\text { chronological order of the rule of the governors of the Principality } \\
\text { of Croatia? }\end{array}$ & $\begin{array}{l}\text { 1. Remembering and providing pre-learned facts } \\
\text { and information }\end{array}$ \\
\hline $\begin{array}{l}\text { 34. Which sequence correctly determines the correct cause- } \\
\text { consequence order of events related to the Reformation? }\end{array}$ & $\begin{array}{l}\text { 1. Remembering and providing pre-learned facts } \\
\text { and information }\end{array}$ \\
\hline $\begin{array}{l}\text { 35. Which sequence determines the correct chronological order } \\
\text { of the events of national formation in Croatia in the19th century? }\end{array}$ & $\begin{array}{l}\text { 1. Remembering and providing pre-learned facts } \\
\text { and information }\end{array}$ \\
\hline $\begin{array}{l}\text { 36. Which sequence determines the correct chronological order } \\
\text { of events in the process of the Unification of Germany? }\end{array}$ & $\begin{array}{l}\text { 1. Remembering and providing pre-learned facts } \\
\text { and information }\end{array}$ \\
\hline $\begin{array}{l}\text { 37. Which sequence determines the correct chronological order } \\
\text { of the following conferences at the time of World War II? }\end{array}$ & $\begin{array}{l}\text { 1. Remembering and providing pre-learned facts } \\
\text { and information }\end{array}$ \\
\hline $\begin{array}{l}\text { 38. Match the research items with their historical associated } \\
\text { science. }\end{array}$ & $\begin{array}{l}\text { 1. Remembering and providing pre-learned facts } \\
\text { and information }\end{array}$ \\
\hline 39. Match the persons 1-4 with their achievements marked A-F. & $\begin{array}{l}\text { 1. Remembering and providing pre-learned facts } \\
\text { and information }\end{array}$ \\
\hline $\begin{array}{l}\text { 40. Match the following Croatian historical literary works with their } \\
\text { authors. }\end{array}$ & $\begin{array}{l}\text { 1. Remembering and providing pre-learned facts } \\
\text { and information }\end{array}$ \\
\hline $\begin{array}{l}\text { 41. Carefully examine the map of Croatian territory at the time of } \\
\text { the conflict with the Turks. } \\
\text { Map }\end{array}$ & $\begin{array}{l}\text { 1. Remembering and providing pre-learned facts } \\
\text { and information }\end{array}$ \\
\hline $\begin{array}{l}\text { 42. Match the rulers 1-4 with the appropriate events from A-F at } \\
\text { the time of their rule. }\end{array}$ & $\begin{array}{l}\text { 1. Remembering and providing pre-learned facts } \\
\text { and information }\end{array}$ \\
\hline $\begin{array}{l}\text { 43. Carefully examine the map and the travel paths marked by } \\
\text { numbers } 1 \text { to } 4 \text { and match them with the appropriate explorer. }\end{array}$ & $\begin{array}{l}\text { 1. Remembering and providing pre-learned facts } \\
\text { and information }\end{array}$ \\
\hline $\begin{array}{l}\text { 44. Carefully examine the front pages of newspapers. Match } \\
\text { them with the period of their inception. }\end{array}$ & $\begin{array}{l}\text { 1. Remembering and providing pre-learned facts } \\
\text { and information }\end{array}$ \\
\hline $\begin{array}{l}\text { 45. Match the political and military alliances 1-4 with their } \\
\text { members from A-F. }\end{array}$ & $\begin{array}{l}\text { 1. Remembering and providing pre-learned facts } \\
\text { and information }\end{array}$ \\
\hline $\begin{array}{l}\text { 46. Match the Croatian political parties from the19.th century1-4 } \\
\text { with their political leaders from A-F. }\end{array}$ & $\begin{array}{l}\text { 1. Remembering and providing pre-learned facts } \\
\text { and information }\end{array}$ \\
\hline $\begin{array}{l}\text { 47. Match the political events 1-4 with the appropriate year and } \\
\text { country from A-F. }\end{array}$ & $\begin{array}{l}\text { 1. Remembering and providing pre-learned facts } \\
\text { and information }\end{array}$ \\
\hline $\begin{array}{l}\text { 48. Carefully examine the historical map of Croatian and Bosnian } \\
\text { and Herzegovinian territory before World War I. Areas in the map } \\
\text { marked 1-4 match with the administrative legal statuses marked } \\
\text { A-F. }\end{array}$ & $\begin{array}{l}\text { 1. Remembering and providing pre-learned facts } \\
\text { and information }\end{array}$ \\
\hline $\begin{array}{l}\text { 49. Carefully examine the historical map of the division of the } \\
\text { Kingdom of Yugoslavia at the beginning of World War II. Match } \\
\text { the areas marked } 1 \text { to } 4 \text { with their political -territorial status } \\
\text { marked A-F. }\end{array}$ & $\begin{array}{l}\text { 1. Remembering and providing pre-learned facts } \\
\text { and information }\end{array}$ \\
\hline $\begin{array}{l}\text { 50. Carefully examine the historical map from the time of World } \\
\text { War I. Match the areas marked from } 1 \text { to } 4 \text { to the military actions } \\
\text { marked A-F. }\end{array}$ & $\begin{array}{l}\text { 1. Remembering and providing pre-learned facts } \\
\text { and information }\end{array}$ \\
\hline
\end{tabular}




\begin{tabular}{|c|c|}
\hline $\begin{array}{l}\text { 51. Carefully examine the picture and answer the following } \\
\text { questions. }\end{array}$ & $\begin{array}{l}\text { 1. Remembering and providing pre-learned facts } \\
\text { and information }\end{array}$ \\
\hline 51.1. What is the name of the building shown in the picture? & $\begin{array}{l}\text { 1. Remembering and providing pre-learned facts } \\
\text { and information }\end{array}$ \\
\hline 51.2. Name the civilisation which first erected such buildings. & $\begin{array}{l}\text { 1. Remembering and providing pre-learned facts } \\
\text { and information }\end{array}$ \\
\hline \multicolumn{2}{|l|}{$\begin{array}{l}\text { 52. Carefully examine the historical map of the Roman Provinces } \\
\text { and answer the following questions. }\end{array}$} \\
\hline $\begin{array}{l}\text { 52.1. Which Roman Emperor made this administrative-territorial } \\
\text { division of the territory as shown on the map? }\end{array}$ & $\begin{array}{l}\text { 1. Remembering and providing pre-learned facts } \\
\text { and information }\end{array}$ \\
\hline $\begin{array}{l}\text { 52.2. Which town was the main business and administrative } \\
\text { centre of Druga Panonija (Panonie Secunde)? }\end{array}$ & $\begin{array}{l}\text { 1. Remembering and providing pre-learned facts } \\
\text { and information }\end{array}$ \\
\hline $\begin{array}{l}\text { 52.3. What is the name of the form of power in the division of the } \\
\text { Empire into } 4 \text { prefectures with } 4 \text { joint rulers? }\end{array}$ & $\begin{array}{l}\text { 1. Remembering and providing pre-learned facts } \\
\text { and information }\end{array}$ \\
\hline $\begin{array}{l}\text { 53. Carefully examine the picture of the remains of the historical } \\
\text { town before Columbus discovered America and answer the } \\
\text { following questions }\end{array}$ & $\begin{array}{l}\text { 1. Remembering and providing pre-learned facts } \\
\text { and information }\end{array}$ \\
\hline 53.1. Which nation before Columbus built this town? & $\begin{array}{l}\text { 1. Remembering and providing pre-learned facts } \\
\text { and information }\end{array}$ \\
\hline 53.2. What is this town called? & $\begin{array}{l}\text { 1. Remembering and providing pre-learned facts } \\
\text { and information }\end{array}$ \\
\hline 53.3. Which script did this nation use? & $\begin{array}{l}\text { 1. Remembering and providing pre-learned facts } \\
\text { and information }\end{array}$ \\
\hline $\begin{array}{l}\text { 54. Carefully examine the historical map of the Mediterranean in } \\
\text { the early middle ages and answer the following questions }\end{array}$ & $\begin{array}{l}\text { 1. Remembering and providing pre-learned facts } \\
\text { and information }\end{array}$ \\
\hline $\begin{array}{l}\text { 54.1. Which nation's conquests and expansion is shown in this } \\
\text { map? }\end{array}$ & $\begin{array}{l}\text { 1. Remembering and providing pre-learned facts } \\
\text { and information }\end{array}$ \\
\hline $\begin{array}{l}\text { 54.2. Which military general stopped their further expansion into } \\
\text { Western Europe? }\end{array}$ & $\begin{array}{l}\text { 1. Remembering and providing pre-learned facts } \\
\text { and information }\end{array}$ \\
\hline 54.3. What was the name of their country on European soil? & $\begin{array}{l}\text { 1. Remembering and providing pre-learned facts } \\
\text { and information }\end{array}$ \\
\hline $\begin{array}{l}\text { 55. Read the excerpts from this original historical text and answer } \\
\text { the following questions. }\end{array}$ & $\begin{array}{l}\text { 1. Remembering and providing pre-learned facts } \\
\text { and information }\end{array}$ \\
\hline $\begin{array}{l}\text { 55.1. When and where was the ecclesiastical parliament held, for } \\
\text { which this letter was meant? }\end{array}$ & $\begin{array}{l}\text { 1. Remembering and providing pre-learned facts } \\
\text { and information }\end{array}$ \\
\hline $\begin{array}{l}\text { 55.2. In which language were the holy rites held by order of this } \\
\text { parliament? }\end{array}$ & $\begin{array}{l}\text { 1. Remembering and providing pre-learned facts } \\
\text { and information }\end{array}$ \\
\hline $\begin{array}{l}\text { 55.3. Which person was in opposition by the decision of this } \\
\text { parliament? }\end{array}$ & $\begin{array}{l}\text { 1. Remembering and providing pre-learned facts } \\
\text { and information }\end{array}$ \\
\hline $\begin{array}{l}\text { 56. Carefully examine the historical source from the second half } \\
\text { of the 19th century and answer the following questions. }\end{array}$ & $\begin{array}{l}\text { 1. Remembering and providing pre-learned facts } \\
\text { and information }\end{array}$ \\
\hline $\begin{array}{l}\text { 56.1. Following the signing of which legal and political document } \\
\text { was this pamphlet published? }\end{array}$ & $\begin{array}{l}\text { 1. Remembering and providing pre-learned facts } \\
\text { and information }\end{array}$ \\
\hline 56.2. What year was that document signed? & $\begin{array}{l}\text { 1. Remembering and providing pre-learned facts } \\
\text { and information }\end{array}$ \\
\hline $\begin{array}{l}\text { 56.3. Which language in which the document was published } \\
\text { became the official language in Croatia? }\end{array}$ & V \\
\hline $\begin{array}{l}57 . \text { Carefully examine the given illustration and answer the } \\
\text { following questions. }\end{array}$ & $\begin{array}{l}\text { 1. Remembering and providing pre-learned facts } \\
\text { and information }\end{array}$ \\
\hline $\begin{array}{l}\text { 57.1. What is the name of the international institution symbolised } \\
\text { by this logo? }\end{array}$ & $\begin{array}{l}\text { 1. Remembering and providing pre-learned facts } \\
\text { and information }\end{array}$ \\
\hline $\begin{array}{l}\text { 57.2. The victims of which war were the catalyst for the } \\
\text { foundation of this organisation? }\end{array}$ & $\begin{array}{l}\text { 1. Remembering and providing pre-learned facts } \\
\text { and information }\end{array}$ \\
\hline 57.3. What is the name and surname if its founder? & $\begin{array}{l}\text { 1. Remembering and providing pre-learned facts } \\
\text { and information }\end{array}$ \\
\hline
\end{tabular}




\begin{tabular}{|c|c|}
\hline $\begin{array}{l}\text { 58. Carefully examine the historical map of Croatian territory in } \\
\text { the 18th century and answer the following questions. }\end{array}$ & \\
\hline $\begin{array}{l}\text { 58.1. During which rule did such a territorial- administrative } \\
\text { division exist? }\end{array}$ & $\begin{array}{l}\text { 1. Remembering and providing pre-learned facts } \\
\text { and information }\end{array}$ \\
\hline $\begin{array}{l}\text { 58.2. What is the name of the body of power under the rule of } \\
\text { which was Croatian territory represented by number } 1 \text { ? }\end{array}$ & $\begin{array}{l}\text { 1. Remembering and providing pre-learned facts } \\
\text { and information }\end{array}$ \\
\hline 58.3. Which three counties were reinstated then? & $\begin{array}{l}\text { 1. Remembering and providing pre-learned facts } \\
\text { and information }\end{array}$ \\
\hline $\begin{array}{l}\text { 59. Carefully examine the historical map of the Kingdom of Serbs, } \\
\text { Croats and Slovenes and answer the following questions. }\end{array}$ & $\begin{array}{l}\text { 1. Remembering and providing pre-learned facts } \\
\text { and information }\end{array}$ \\
\hline $\begin{array}{l}\text { 59.1. What is the name of the Constitution according to which the } \\
\text { map showing the division of territory of the Kingdom of Serbs, } \\
\text { Croats, and Slovenes called? }\end{array}$ & $\begin{array}{l}\text { 1. Remembering and providing pre-learned facts } \\
\text { and information }\end{array}$ \\
\hline 59.2. What kind of politics was legalised by that Constitution? & $\begin{array}{l}\text { 1. Remembering and providing pre-learned facts } \\
\text { and information }\end{array}$ \\
\hline $\begin{array}{l}\text { 59.3. By which royal union was the displayed territorial division of } \\
\text { the Kingdom of Serbs, Croats and Slovenes dissolved? }\end{array}$ & $\begin{array}{l}\text { 1. Remembering and providing pre-learned facts } \\
\text { and information }\end{array}$ \\
\hline $\begin{array}{l}\text { 60. Carefully examine the photograph taken from the time of the } \\
\text { Homeland War and answer the following questions. }\end{array}$ & $\begin{array}{l}\text { 1. Remembering and providing pre-learned facts } \\
\text { and information }\end{array}$ \\
\hline $\begin{array}{l}\text { 60.1. The destruction of which Croatian town is shown in the } \\
\text { photograph? }\end{array}$ & $\begin{array}{l}\text { 1. Remembering and providing pre-learned facts } \\
\text { and information }\end{array}$ \\
\hline 60.2. On which date was this town occupied? & $\begin{array}{l}\text { 1. Remembering and providing pre-learned facts } \\
\text { and information }\end{array}$ \\
\hline $\begin{array}{l}\text { 60.3. What are the places of the massacre of Croatian soldiers } \\
\text { and citizens of this town called? }\end{array}$ & $\begin{array}{l}\text { 1. Remembering and providing pre-learned facts } \\
\text { and information }\end{array}$ \\
\hline
\end{tabular}

Australia History: Australian History Written Examination

N.B.

All questions request reference to specified various chapters from the high school history textbook.

Questions 1 an 4 are based on input illustrations or an excerpt from a text.

\begin{tabular}{|c|c|}
\hline Question & Rating on Critical Thinking Scale \\
\hline $\begin{array}{l}\text { 1. Section A contains two documents - Document A and } \\
\text { Document B. For Question } 1 \text { you are to answer } \\
\text { all questions for EITHER Document A or Document The } \\
\text { question is based on Unit } 3 \text { Outcome } 1 \text { : } \\
\text { A new land: Port Phillip District/Colony of Victoria 1830-1860. } \\
\text { 1.a/b.i. Identify two changes, as illustrated in this image, that the } \\
\text { arrival of European settlers brought to the } \\
\text { Aborigines in the Port Phillip District. }\end{array}$ & $\begin{array}{l}\text { 1. Remembering and providing pre-learned facts } \\
\text { and information } \\
2 \text { marks }\end{array}$ \\
\hline $\begin{array}{l}\text { 1.a/b.ii. Identify from the document two pieces of evidence that } \\
\text { show Melbourne was a bustling settlement } \\
\text { in } 1852 \text {. }\end{array}$ & $\begin{array}{l}\text { 1. Remembering and providing pre-learned facts } \\
\text { and information } \\
4 \text { marks }\end{array}$ \\
\hline $\begin{array}{l}\text { 1.a/b.iii. Identify and explain two observations made in the } \\
\text { document that illustrate the social attitudes of } \\
\text { many gold rush immigrants. }\end{array}$ & $\begin{array}{l}\text { 1. Understanding Demonstrating understanding of } \\
\text { pre-learned and given information by explaining } \\
6 \text { marks }\end{array}$ \\
\hline $\begin{array}{l}\text { 1.a/b.iv. Evaluate the impact of European settlement on } \\
\text { Aboriginal communities in the Port Phillip District/ } \\
\text { Colony of Victoria. }\end{array}$ & $\begin{array}{l}\text { 2. Understanding Demonstrating understanding of } \\
\text { pre-learned and given information by explaining } \\
8 \text { points }\end{array}$ \\
\hline $\begin{array}{l}\text { 2. Answer the following questions relating to Unit 3, Outcome } 2 \text { : } \\
\text { Nation, race and citizen 1888-1914. } \\
\text { In each case you must support your views with specific } \\
\text { information and evidence. } \\
\text { 2.a Explain two ideas that underpinned the creation of the new } \\
\text { nation. }\end{array}$ & $\begin{array}{l}\text { 2. Understanding Demonstrating understanding of } \\
\text { pre-learned and given information by explaining } \\
4 \text { marks }\end{array}$ \\
\hline $\begin{array}{l}\text { 2.b Discuss to what extent the benefits gained and the } \\
\text { responsibilities accepted by women as citizens of the new nation } \\
\text { differ from those of men }\end{array}$ & $\begin{array}{l}\text { 2.Applying Comparing and contrasting both } \\
\text { previous and given information } \\
6 \text { marks }\end{array}$ \\
\hline
\end{tabular}




\begin{tabular}{|c|c|}
\hline $\begin{array}{l}\text { 2.c Evaluate the extent to which legislation introduced between } \\
1901 \text { and } 1914 \text { achieved the hopes that had } \\
\text { led to the creation of the new nation. }\end{array}$ & $\begin{array}{l}\text { 2. Understanding Demonstrating understanding of } \\
\text { pre-learned and given information by explaining } \\
10 \text { marks }\end{array}$ \\
\hline $\begin{array}{l}\text { 3. In essay form answer either a., b. or c. for Question 3. This } \\
\text { question is based on Unit 4, Outcome 1:Testing the new nation } \\
\text { 1914-1950. } \\
\text {.a.'Australian society did not change significantly during World } \\
\text { War I.' } \\
\text { To what extent do you agree with this statement? } \\
\text { OR } \\
\text { b. 'Divisions in society virtually disappeared during the crisis of } \\
\text { the Great Depression.' } \\
\text { To what extent do you agree with this statement? } \\
\text { OR } \\
\text { c. 'For many Australians World War II provided new experiences } \\
\text { and opportunities for change.' } \\
\text { To what extent do you agree with this statement? }\end{array}$ & $\begin{array}{l}\text { 5. Assessing Assessing given information, providing } \\
\text { valued judgements about information, with } \\
\text { justifiable reasons } \\
20 \text { marks }\end{array}$ \\
\hline $\begin{array}{l}\text { 4. Analyse one of the documents, commentaries or quotations in } \\
\text { the insert relating to Unit 4, Outcome 2: Debating } \\
\text { Australia's future 1960-2000. } \\
\text { Your response should include } \\
\text { - identification of the attitudes reflected in the representation. Use } \\
\text { evidence from the representation to support } \\
\text { your comments } \\
\text { - evaluation of the degree to which the representation reflects } \\
\text { attitudes about the issues that you have studied } \\
\text { at that particular point in time } \\
\text { - analysis of changing attitudes in relation to this issue. To } \\
\text { support your comments, use evidence from the } \\
\text { other point in time that you have studied. }\end{array}$ & $\begin{array}{l}\text { 5. Assessing Assessing given information, providing } \\
\text { valued judgements about information, with } \\
\text { justifiable reasons } \\
\text { 4. Analysing Interpreting information determining the } \\
\text { causes and consequences of information } \\
\text { 3.Applying Comparing and contrasting both } \\
\text { previous and given information } \\
\text { 2. Understanding Demonstrating understanding of } \\
\text { pre-learned and given information by explaining } \\
20 \text { marks }\end{array}$ \\
\hline
\end{tabular}

\section{Research Results}

Comparison between the analysis of the two countries' school leaving examinations questions in terms of critical thinking can be more clearly viewed by comparing the numerical results and the graphical illustration of results viewed side by side.

Legend

Ct $1=$ critical thinking level 1 remembering

Ct 2 = critical thinking level 2 explaining

Ct $3=$ critical thinking level 3 applying

Ct $4=$ critical thinking level 4 analysing

Ct $5=$ critical thinking level 5 assessing

Ct $6=$ critical thinking level 6 creating

Australia

\begin{tabular}{|c|c|c|c|c|c|c|}
\hline Ct 1 & Ct2 & CT3 & CT4 & CT5 & CT6 & Total number of questions \\
\hline 0 & 2 & 1 & 1 & 5 & 0 & 9 \\
\hline $0 \%$ & $22.22 \%$ & $11.11 \%$ & $11.11 \%$ & $55.55 \%$ & 0 & $100 \%$ \\
\hline
\end{tabular}

Croatia

\begin{tabular}{|c|c|c|c|c|c|c|}
\hline CT 1 & CT 2 & CT 3 & CT 4 & CT 5 & CT 6 & Total number of questions \\
\hline 62 & 0 & 0 & 0 & 0 & 0 & 62 \\
\hline $100 \%$ & 0 & 0 & 0 & 0 & 0 & $100 \%$ \\
\hline
\end{tabular}




\section{Comparative Graphical representation}

\subsection{History}
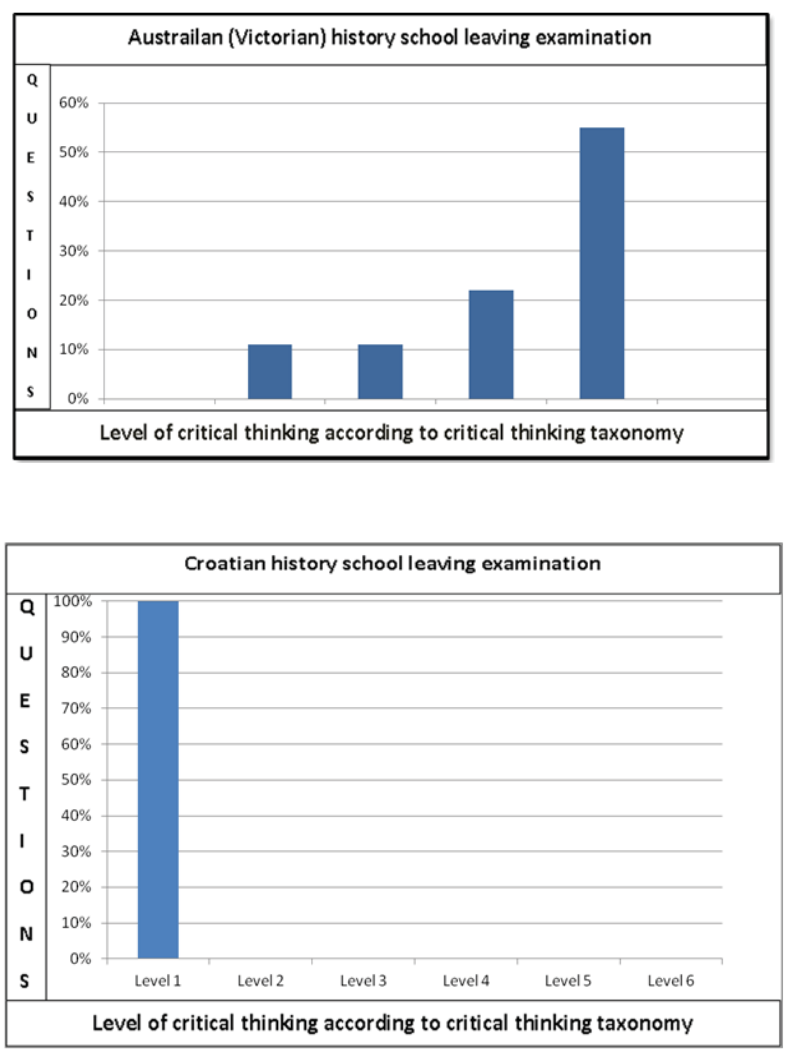

\section{Analysis of Results}

The Croatian history examination had a high, in fact sole concentration of a single low level critical thinking skill at level one which involves providing pre-learned facts as its aim. The Australian history examination questions demanded higher levels of critical thinking. One could conclude that there is a huge difference between what is demanded of students in terms of critical thinking skills between Australia and Croatia.

It was interesting to note that the skills from the Australian paper were intertwined within questions which meant in one question demanded the demonstration of more than one skill within the same question.

The Croatian history paper's questions all asked for the same skill, i.e. remembering pre-learned information. One mark was awarded for each correct answer and was therefore commensurate with the level of skill, that is weighting of marks equalled the demanded skill.

In the Australian history paper, the questions demanded a variety of critical thinking skills and marks varied, mostly hierarchically in keeping with the level of skill required, that is lower level demanded critical thinking skill was awarded lower mark, higher demanded critical thinking skill was given higher marks, but not always.

Interestingly, creativity was not included as a separately demanded skill in either examination paper. Awarding marks for creativity might be difficult and subjective for an examination such as this which is designed to rank students for entry into university.

There is a considerable difference in the types of answers sought. The Australian paper's answer must be in written, complete sentences, paragraph form. The Croatian paper's answers consist of multiple choice, a single word or phrase or mix and match. Does this reflect what skills and competences are taught in the respective schools? 


\section{Conclusion}

It is obvious that questions that promote higher levels of critical thinking skills are represented more in Australian history examination matriculation paper then in the Croatian one. One recommendation stemming from this research is that higher level critical thinking skills need to be promoted more in the Croatian history paper. This is more the case in the Australian history paper. However, more work needs to done on the Australian history marking scheme to make allocation of marks more commensurate with the level of critical thinking skill. Further research would be interesting to determine on the extent to which this reflection of critical thinking skills in examination papers is also a reflection of what is taught in class.

\section{References}

Brown and Keeley, (2201)Asking the right questions- A Guide to Critical thinking (3rd Ed.) New Jersey Prentice Hall Inc

Facione, P.A. The Disposition Towrads Critical Thinking: Its Character, Measurement, and Relationship to Critical Thinking Skill Informal Logic Vol. 20, N01: pp.61-84

Anderson, Lorin W and Krathwohl, David R 2001 A Taxonomy for learning, Teaching and Assessing: a Revsion of Bloom's Taxonomy.New York. Longman

Atkinson, R.C and Geiser S. (1981) Reflections ona Century of College Admissions Tests Educational Researcher 2009;38;665

Bloom, B. S. (ed.) (1956) Taxonomy of Educational Objectives, the classification of educational goals - Handbook I: Cognitive Domain New York: McKay

Bloom, B. S. (ed.) (1956) Taxonomy of Educational Objectives, the classification of educational goals - Handbook I: Cognitive Domain New York: McKay

Carey, S (2000) The Uses and abuses of ArgumentMayfield Publishing Company

Clement and Lochhead, 1980, Cognitive Process Instruction.

Dewey J. (1933) How we think: A restatement of the relation of reflective thinking to the education process Boston: Heath

Ennis, R, H .(1985) . A Logical Basis for Measuring Critical Thinking Skills. Educational Leadership,43 (2): 44-48 .

Facione P.A (2000) The Disposition Towrad Critical Thinking: Its Character, Measurement and Relationship to Critical Thinking Skill Informal Logic Vol 20, No1 pp.61-84

Garavalia, L., Hummel, J., Wiley, L., \& Huitt, W. (1999). Constructing the course syllabus: Faculty and student perceptions of important syllabus components. Journal of Excellence in College Teaching, 10(1), 5-22.

Halpern D F (1996) Thought and Knowledge: an Introduction into CriticalTthinking (3rd) edition Mawah NJ:Erblaum

http://www.criticalthinking.org/aboutCT/Research.cfm

http://www.edpsycinteractive.org/topics/cogsys/bloom.html

http://www.wolcottlynch.com/Downloadable_Files/StudentAssumptions.pdf

Huitt, W. (1998). Critical thinking: An overview. Educational Psychology Interactive. Valdosta, GA: Valdosta State University. Retrieved [date] from, http://www.edpsycinteractive.org/topics/cogsys/critthnk.html. [Revision of paper presented at the Critical Thinking Conference sponsored by Gordon College, Barnesville, GA, March, 1993.

Huitt, W. (2009). Bloom et al.'s taxonomy of the cognitive domain. Educational Psychology Interactive. Valdosta, GA: Valdosta State University.

Kalin, B. Logika i oblikovanje kritičkog mišljenja- Logic and shaping of critical thnking. Škloska Knjiga Zagreb p.8

Kleitzein, Vizek.Vidovič, Bekavac (2005), Active learning and the EER framework for teaching, aktivno ućenje $i$ EER okvir za poučavanje, za slobodu odgoja Zagreb Forum Čitanje i pisanje za kritičkog razmišljanje

Kurfiss, J.G (1988) Critical thinking: Theory, research, practice and possibilities.AsHE-ERIC Higher Education Report No.2 Washington DC George Washington University

Langreher, J (2005) Assessing creative and critical thinking Hawker Brownlow

Langreher, J. (2005) Assessing creative and critical thinking Hawker Brownlow

Langrehr J (2005) Assessing Creative and Critical Thinking Hawker Brwnlow

Miškulin I (2008) Anticorruption education in schools - a handbook for teachers (Antikorrupcijsko obrazovaje u školama), Forum for free Education Zagreb

Nacionalni okvirni kurikulum za preškolskiodgoj i opće obrazovanje u osnovnoj i srednoj školi - National Curriculum for pre-school and compulsory primary and secondary education, Zagreb, studeni 2008 p.13

Noddings N (2006) Critical lessons What our schools should teach Cambridge University Press

Paul R W (1993) What evryone needs to survive in a rpidly changing world T Wilson and JA Binker eds Santa RosaCA Foundation for Critical Thinking.

Pithers, R.T. and Soden, R. (2000) Critical thinking in education: a review Educational Research, Vol 42 October 2000

Potts, Bonnie (1994). Strategies for teaching critical thinking. Practical Assessment, Research \& Evaluation, 4(3). Retrieved August 7 , 2010 from http://PAREonline.net/getvn.asp?v=4\&n=3.

Quellmalz E S ((1985) Needed : Better Methods for Testing Higher Order Thinking Skills Educational Leadership 
Robert Todd Carroll (2004) Becoming a Crtical Thinker- A guide for the New Millenium

Ruggiero V (1996) A Guide to Sociological thinking Sage Publications

Salleh $\mathrm{H}$ and Tan C (2006) Using television commercials and movies to promote critical thinking in primary science and mathematics education Neos 1 (2006) 83-98

Schaferman, S. (1991) An Introduction to critical thinking http://www.freeinquiry.com/critical-thinking.html

Scriven, M (1985) Critical for Survival National Forum. 559-12.

Serap, E. (2009) Education faculty students' critical thinking disposition according to academic achievement Procedia-Social and Behavioural Sciences Vol1, issue1,2009.pp.2456-2469

Suhor, C.( 1984) Thinking Skills in English--And across the Curriculum. ERIC Digest.

ERIC Document Reproduction Service No ED250693

Urr P. (2005) A Course in Language Teaching CUP

Walton, D (2008) Informal logic - a pragmatic approach. CUP

www.insightassessment.com/pdf_files/DEXadobe.PDF

Yeh. S, Tests worth teaching to: Constructing state mandated tests that emphasise critical thinking Educational Researcher $200130: 12$ DOI: $10.3102 / 0013189 \times 030009012$ 